MA ALEKSANDAR RAKONJAC, istraživač-pripravnik

Institut za noviju istoriju Srbije

Beograd, Republika Srbija

aleksandar.rakonjac90@gmail.com

originalan naučni rad

UDK: 338.1(497.1)"1944/1947"

primljeno: 8. maj 2017.

$338.45(497.1) " 1944 / 1947 "$

prihvaćeno: 28. mart 2018.

https://doi.org/10.29362/ist20veka.2018.2.rak.87-100

\title{
OBNOVA JUGOSLOVENSKE INDUSTRIJE 1944-1947. IDEJE, PLANOVI, PRAKSA*
}

APSTRAKT: Period obnove Jugoslavije odvijao se istovremeno na više koloseka, a privredni je, prema shvatanju državnog rukovodstva, bio od primarne važnosti. U strategiji privredne obnove zemlje industrija je zauzimala istaknuto mesto i od njene uspešne rekonstrukcije zavisila je brza obnova ostalih grana privrede. Obnova industrije je u kratkoročnim projekcijama rukovodstva jugoslovenskih komunista bila ključna stvar bez koje dugoročna strategija usvajanja sovjetskog komandno-planskog privrednog modela ne bi bila izvodljiva u jugoslovenskim uslovima.

KLJUČNE REČI: Jugoslavija, industrija, obnova, planiranje, Komunistička partija Jugoslavije

\section{Strategijski okviri obnove}

Privrednu obnovu zemlje jugoslovenski komunisti su sagledavali prema potrebama koje su određivale složene posleratne okolnosti. Za njih je „obnoviti“ značilo ponovo sagraditi i uspostaviti porušeno i uništeno na ranijim temeljima, ali prema boljem planu, sa solidnijim materijalom i u skladu sa odgovarajućim potrebama novog vremena. Ovaj poslednji uslov nagoveštavao je otpisivanje svih onih privrednih subjekata čija namena više nije odgovarala trenutnim potrebama društva. Prema njihovom shvatanju, privredna obnova zemlje predstavljala je javni interes par excellence. Privatna inicijativa nije mogla da igra značajniju ulogu u tako grandioznom poduhvatu, već je čitavo društvo, uz međunarodnu pomoć i saradnju, jedino bilo sposobno da do kraja obavi taj posao. Pošto je preovladalo shvatanje da u procesu obnove ne bi trebalo bespotrebno rasipati snage na obnovu onih fabrika $i$ industrijskih postrojenja čija je proizvodna uloga u novim okolnostima izgubila namenu, okretanje ka modernizaciji

\footnotetext{
${ }^{*}$ Rad je deo projekta Srbi i Srbija u jugoslovenskom i međunarodnom kontekstu: unutrašnji razvitak $i$ položaj u evropskoj/svetskoj zajednici, (47027), koji finansira Ministarstvo prosvete, nauke i tehnološkog razvoja Republike Srbije.
} 
industrijske proizvodnje bio je jedan od zadataka koji je trebalo da bude obavljen u sklopu privredne obnove zemlje. Time je doveden u pitanje opstanak niza industrijskih pogona koji nisu imali povoljne prirodne i tehničke uslove da razviju masovnu proizvodnju na korist potrošača, već su opstajali uživajući visoku carinsku protekciju, ne pružajući time mogućnost širokim krugovima potrošača da dođu do jevtinijih proizvoda. Sa ovakvom politikom trebalo je raskrstiti i pomoći obnovu isključivo ekonomski racionalnih preduzeća, koja su bila u stanju da proizvedu kvalitetan i jevtin proizvod. Stoga, kako bi se sve ovo ostvarilo u procesu obnove i izgradnje, glavni cilj ,nove“ države bio je da spreči regionalnu autarhiju federalnih jedinica, ne dozvoli njihovo ekonomsko ograđivanje, uvođenje diferencijalnog tretiranja proizvoda iz drugih federalnih jedinica i vođenje samostalne ekonomske politike. Nasuprot tome, imperativ je bila izgradnja zajedničkog tržišta, prihvatanje opštih smernica u vođenju ekonomske politike i, ono što je bilo najvažnije u tim okolnostima, ravnomerna raspodela sredstava iz Fonda za obnovu zemlje. ${ }^{1}$

\section{„Neplanska“ faza obnove tokom 1945. godine}

Opšti konsenzus rukovodstva jugoslovenskih komunista po pitanjima strategije obnove nije bio upitan. Druga polovina 1945. godine bila je obeležena problemima konsolidacije vlasti u zemlji, a za to vreme poslovi na obnovi nisu mogli da pređu strogo na osnovu planiranja. Uprkos svim poteškoćama, entuzijazma nije manjkalo. ${ }^{2}$ Nova vlast je maksimalno naprezala partijsku mašineriju i vešto koristila agitprop aparat da mobiliše stanovništvo i rasplamsa radni elan. ${ }^{3}$ Glavnina tereta obnove tokom druge polovine 1945. godine pala je na sreske i gradske narodne odbore, koji su bili zaduženi za lociranje i saniranje onog dela štete koji je mogao vlastitim sredstvima da bude obavljen. U njihovoj direktnoj nadležnosti bila su preduzeća koja nisu projektovana da potpadnu pod kategoriju preduzeća od opštedržavnog značaja, a viša instanca sa kojom su bili dužni da sarađuju na poslovima obnove bila su republička ministarstva industrije, kojima su se lokalni narodni odbori obraćali za pomoć u slučajevima kada je nedostajalo vlastitih sredstava. ${ }^{4}$

Primarni zadatak novih upravitelja ovih preduzeća bio je procena štete i popis svih potencijalnih domaćih sredstava obnove. Po završetku tog posla, oni su, budući da su apsolutnu većinu novih upravnika činili inženjeri i kvalifikovani radnici, prema sopstvenim znanjima i mogućnostima organizovali obnovu fabrika. Uz ove zadatke, koji su proizilazili iz njihovih kompetencija, imali su dužnost da šalju mesečne izveštaje u kojima su savezno ministarstvo industrije obaveštavali

\footnotetext{
${ }^{1}$ Arhiv Jugoslavije (AJ), fond 41, Savezna planska komisija (SPK), 41-5-5, Studija o privrednoj obnovi zemlje (1945).

${ }^{2}$ AJ, SPK, 41-8-9, Referat sekretara Komisije za privrednu obnovu zemlje B. Kuglera (26. januar 1946).

${ }^{3}$ Ljubodrag Dimić, Agitprop kultura: agitpropovska faza kulturne politike u Srbiji: 1945-1952 (Beograd: Rad, 1988), 75-77.

${ }^{4}$ AJ, fond 17, Ministarstvo industrije FNRJ (MI FNRJ), 17-148-149, Troškovi obnove industrijskih preduzeća po republikama (1945-1946).
} 
o toku obnove, utrošenim sredstvima za materijal i nadnice radnika, te neophodnim sredstvima za dalju obnovu u slučaju da su sva domaća iscrpljena i ostalim stvarima striktno vezanim za samo preduzeće koje im je bilo dodeljeno na upravu. Nastojanjima da se osigura brža obnova ovih preduzeća i da se što pre u njima pokrene proizvodnja, svesrdno su doprinosili Fond za obnovu zemlje i Industrijska banka FNRJ. Nepisano pravo prečeg izdavanja kredita saveznoj industriji, više je nego očigledno. O tome svedoči tempo obnove nekih preduzeća od opštedržavnog značaja. Pojedine od takvih fabrika koje su potpuno obnovljene 1945. godine iz industrija odevnih predmeta i obuće bile su „Prva srpska tekstilna fabrika“ iz Niša, ,Tekstilna industrija Živojin Vukojčić i sinovi““ iz Zemuna, „Beogradska tekstilna industrija a.d.“, fabrika koža i obuće koncerna „BATA“ iz Beograda, kompletna druga fabrika gume i obuće koncerna „BATA“ u Borovu, državna fabrika koža „Balkan“ iz Niša, tekstilna fabrika „Motvoz in platno d.d.“" Grosuplje, „Osiječka tvornica koža d.d.“, tekstilna fabrika „Ivančica“" iz Zagreba i državno preduzeće za preradu vune iz Paraćina. ${ }^{5}$

Građevinskoj industriji, nesumnjivo jednoj od najvažnijih za obnovu zemlje, posvećena je velika pažnja. Radovi na obnovi završeni su u državnoj pilani „Zlatar“ iz Nove Varoši, ciglani „Ibar“ iz Kraljeva, ciglani „Rekord“ iz Jagodine, preduzeću „Državna fabrika gipsa“ iz Beograda, fabrici šamota iz Mladenovca, „Beočinskoj fabrici cementa a.d. “6, „Metal i farbe a.d.“" iz Beograda, ciglani u Oriovcu pored Osijeka, fabrici crepa i opeke u Sinju, drvnoj industriji „Lepa“ iz Lepoglave, fabrici za impregnaciju drveta „Impreka“ iz Ribnice (Slovenija), najmodernijoj pilani u predratnoj Jugoslaviji „Šipad“ iz Zavidovića u Bosni i državnoj cementari „Šar“ kod Đeneral Jankovića u Makedoniji. Uspeh na polju obnove savezne industrije primetan je i kod ostalih grana industrije. Potpuno su obnovljeni klanica i fabrika za preradu mesa „Srbija“" iz Velike Plane, „Prvi akcionarski mlin a.d.“ Kragujevac, prehrambeno preduzeće „Luxardo“ iz Zadra, „Karolina d.d.“ iz Osijeka i državna uljara iz Velesa. Tu su još fabrike hemijske industrije ,Jugoslovensko azbestno a.d.“ i „Prerada a.d.“ iz Beograda, „Astra d.d.“ iz Vrapča kod Zagreba, fabrika sapuna „Vardar“ iz Skoplja, te metalne „Beometal a.d.“, „Rad“, ,Morava“ i „Proleter“ iz Beograda, „Jugostroj“ iz Rakovice, industrijska kovnica „Sorlini Valter“ Varaždin, fabrika aluminijuma „Lozovac“ kod Šibenika, „Kovina“ Maribor, fabrika navoja „Slavko in Milka Sustersio“ Lesce, državni metalski zavod „Tito“ iz Skoplja. Sve navedene

\footnotetext{
${ }^{5}$ AJ, MI FNRJ, 17-149-150, Troškovi obnove, Savezna industrija 1945-1946.

${ }^{6}$ Fabrika cementa u Beočinu je po oslobođenju stavljena pod prinudnu upravu Državne uprave narodnih dobara (DUND), koja je potom imenovala inženjera Radomira Hajdukovića za prinudnog upravitelja. On se po dolasku u fabriku suočio sa neprijatnom činjenicom da se broj radnika u odnosu na stanje pre rata smanjio za $50 \%$ i da je velika većina njih suočena sa glađu našla zaposlenje kod okolnih krupnih zemljoposednika. Najveću štetu fabrika je pretrpela uništenjem dva velika turbogeneratora i potapanjem rudnika lapora. Agilnošću inž. Hajdukovića, te širokim ovlašćenjima koje je dobio da obnovi rad jedne od najvećih i najmodernijih cementara na Balkanu i svakako pristizanjem bivših radnika na svoja radna mesta, rad na obnovi fabrike dobio je novu dinamiku. Sredinom 1945. fabrika je uspešno obnovljena na predratnom nivou i započela je proizvodnju punim kapacitetima. Nikola L. Gaćeša, Istorija fabrike cementa и Веос̌inu (Novi Sad: Matica srpska, 2008), 93-100; Борба, 18. 6. 1945.
} 
fabrike su samo jedan deo preduzeća od opštedržavne važnosti koja su u potpunosti obnovljena do kraja 1945. godine. Ova preduzeća su zapravo uzorak, jer su to bila uglavnom veća preduzeća, a njihov ukupan broj se ne može pouzdano utvrditi zbog oskudice podataka. Glavni razlog bio je u tome što je značajan deo njih neredovno dostavljao saveznom ministarstvu podatke o procesu obnove. ${ }^{7}$

Poslednja godina rata u Evropi, obeležena sovjetskim uspesima na Istočnom frontu i anglo-američkim u Francuskoj i na Mediteranu, aktuelizovala je ulogu Balkana u ratnoj strategiji saveznika. Sa savezničkim napredovanjem iz ta tri pravca, nemačke i kvislinške jedinice na jugoistoku Evrope našle su se u procepu i pred realnom opasnošću da između ,čekića i nakovnja“ budu uništene. Izvlačenje nemačke Grupe armija E iz Grčke preko jugoslovenske teritorije pojačalo je aktivnost anglo-američke avijacije, koja je ubrzo stekla nadmoć nad balkanskim nebom. Bombardovanje nemačkih položaja od strane savezničke avijacije ,tepih sistemom“, nije samo nanosilo štetu nemačkim oružanim snagama već, naprotiv, mnogo veću štetu trpeli su civili, civilni i privredni objekti. Bombardovanje gradova u Srbiji isticalo se ništa manjom brutalnošću nego ono koje su izvršili Nemci aprila 1941. godine. Naročito veliku štetu pretrpeo je Beograd na Uskrs 1944. godine, a za njim nisu zaostajali ni Leskovac, Niš, Kraljevo i drugi gradovi Srbije. Podgorica je u maju 1944. uništena gotovo do temelja, a štetu je pretrpeo i Nikšić. Bombardovanju su bili izloženi i gradovi u Nezavisnoj Državi Hrvatskoj - Split, Šibenik, Banja Luka i Slavonski Brod, dok je Zadar gotovo sravnjen sa zemljom. Efekat ove vrste bombardovanja, pored toga što je nesumnjivo trebalo da demonstrira savezničku suprematiju nad vojnom mašinerijom Trećeg rajha, prouzrokovao je ogromne ljudske i materijalne žrtve. ${ }^{8}$

Privreda, integrisana u nemačku ratnu mašinu, nije bila pošteđena razaranja. Na svakom koraku je bilo primetno odsustvo selektivnog bombardovanja industrijskih postrojenja. Nemački okupatori i njihovi domaći pomagači prilikom povlačenja nisu uspeli da unište sve privredne objekte, niti su odabir vršili isključivo prema njihovom privrednom značaju, već pre svega u skladu sa rutama povlačenja, lokacijom privrednih objekata na tim pravcima, vremenom do dolaska Crvene armije i NOVJ i sudarom dve ratujuće strane u fabričkim postrojenjima i oko njih. Primer za to su preduzeća metalne industrije koja su ostala netaknuta. Među tim preduzećima, koja su potom potpala pod preduzeća od opštedržavnog značaja, bile su fabrika vagona i čeličnih konstrukcija „Jasenica“، iz Smederevske Palanke, fabrike „Miron“, „Nestor“ i „Rogožarski“" iz Beograda, „Milan Jakovljević“ iz Zagreba, „Teleoptik“ iz Zemuna i „Utva a.d.“ iz Pančeva. Tu su primeri i iz drugih industrijskih grana, kao što su tekstilna fabrika iz Karlovca, zatim tekstilne fabrike „Perunika“ i „Sidol“ iz Zagreba, „Zagrebačka tvornica cipela d.d.“, „,Srpska fabrika stakla a.d.“ iz Paraćina, fabrika čepova i dugmadi iz Čakovca, „Fabrika hartije a.d.“ iz Čačka, fabrika kože i tanina iz Zagreba, fabrika za proizvodnju žižica „Drava d.d.“ i mnoge druge. Postoje

\footnotetext{
${ }^{7}$ AJ, MI FNRJ, 17-149-150, Troškovi obnove, Savezna industrija 1945-1946.

${ }^{8}$ Branko Petranović, Srbija u Drugom svetskom ratu: 1941-1945 (Beograd: Vojnoizdavački i novinski centar, 1992), 614-615.
} 
primeri gde fabrike zapravo nisu nastradale u ratnim dejstvima, već su njihove mašine usled maksimalnog izrabljivanja postale neupotrebljive, pa ih je trebalo revitalizovati ili zameniti novijim, a to je bio slučaj fabrike kože iz Slovenske Konjice i fabrike stakla iz Paraćina. ${ }^{9}$

Situacija na terenu je često nalagala da se temeljnije promisli o budućoj lokaciji pojedinih fabrika, pa su time neka manja preduzeća potpuno nestajala sa spiska postojećih, jer su lokalni izvršni organi dosledno sprovodili inicijativu centralnih vlasti o potrebi ukrupnjavanja privrednih društava. Na tragu te, među jugoslovenskim komunistima, opšteprihvaćene paradigme, koja je tokom 30-ih godina sprovedena u SSSR-u, bila je fabrika cipela „Sebra“ iz Subotice koja je fuzionisana sa većom fabrikom iz iste branše takođe iz Subotice, fabrikom „Marika“. ${ }^{10}$ Bilo je i drugačijih primera, pa je tako likvidirana „Tvornica ulja d.d.“ iz Koprivnice ustupila železne nosače, osovine i kuglične ležajeve građevinskom preduzeću „Jugobeton“ iz Zagreba, a ova sredstva su potom upotrebljena za sanaciju cele fabričke zgrade i $80 \%$ mašina. ${ }^{11}$ Postojala su i preduzeća čija je obnova posmatrana kroz njihovo predratno poslovanje, koje je bilo uslovljeno blizinom i obilatošću sirovinskih resursa, kao i cenom njihovog transporta do proizvodnih pogona. Tako je bosanskohercegovačko rukovodstvo donelo odluku da fabrika šećera „Usora“ iz Doboja, fabrike metalne industrije „Sartid a.d.“ iz Višegrada i „Trijumf“' iz Sarajeva koje su potpuno uništene, zbog nerentabilnog poslovanja i skupe proizvodnje pre rata, budu ugašene. ${ }^{12}$

\begin{tabular}{|c|c|c|c|c|c|c|c|c|c|c|c|c|c|}
\hline Vrednost & \multicolumn{2}{|c|}{ Metalna } & \multicolumn{2}{|c|}{ Elektro } & Hemijska & \multicolumn{2}{|c|}{ Tekstilna } & \multicolumn{2}{|c|}{ Prehrambena } & \multicolumn{2}{|c|}{$\begin{array}{c}\begin{array}{c}\text { Drvna i } \\
\text { građ. }\end{array} \\
\end{array}$} & \multicolumn{2}{|c|}{ Ukupno } \\
\hline predratna & \multicolumn{2}{|c|}{1.370} & \multicolumn{2}{|c|}{2.316} & 885 & \multicolumn{2}{|c|}{1.944} & \multicolumn{2}{|c|}{2.770} & \multicolumn{2}{|c|}{1.752} & \multicolumn{2}{|c|}{11.037} \\
\hline šteta & 134 & $9,8 \%$ & 489 & $22,6 \%$ & \begin{tabular}{|l|l|}
353 & $\mathbf{3 9 , 9} \%$ \\
\end{tabular} & 1.037 & $53,3 \%$ & 604 & $22 \%$ & 289 & $16,5 \%$ & 2.914 & $26,5 \%$ \\
\hline \multicolumn{14}{|c|}{ Obnovljeno prema ratnoj šteti u 1945. godini } \\
\hline obnovljeno & 63 & $46,9 \%$ & 83 & $16,9 \%$ & $10529,6 \%$ & 52 & $5,6 \%$ & 45 & $7,5 \%$ & 104 & $36 \%$ & 453 & $15,5 \%$ \\
\hline
\end{tabular}

Završetkom prvog ciklusa obnove poslednjih dana decembra 1945. godine, kada je pričinjena materijalna šteta industriji već bila popisana i radovi na njenoj obnovi uveliko trajali, na dnevni red Ministarstva industrije FNRJ došao je zadatak izvršenja preseka stanja uloženog i učinjenog u 1945. Procena štete koja je izvršena samo nekoliko meseci po završetku Drugog svetskog rata predstavila je razmere oštećenja svih grana industrije. Nešto više od 1/4 industrijskih postroje-

\footnotetext{
${ }^{9}$ AJ, MI FNRJ, 17-149-150, Troškovi obnove, Savezna industrija 1945-1946.

${ }^{10}$ AJ, MI FNRJ, 17-147-148, Izveštaj o radovima obnove za mesec maj 1946. godine, Fabrika cipela „Sebra“.

11 AJ, MI FNRJ, 17-147-148, Izveštaj o radovima obnove za mesec jul 1946. godine, Državno industrijsko građevinsko preduzeće „Jugobeton“.

12 AJ, MI FNRJ, 17-147-148, Podaci o obnovi preduzeća Narodne Republike BiH za 1945. godinu (30. maj 1946).
} 
nja bilo je ,izbačeno iz stroja“, a najveću štetu su pretrpele tekstilna $(53,3 \%)$, hemijska $(39,9 \%)$ i prehrambena $(22 \%)$ grana industrije. Međutim, iako su najviše oštećene, rezultati obnove otkrivaju drugačije prioritete privrednih stratega. Tako je, ako se uspostavi korelacija sa ostalim granama industrije, u obrnutoj srazmeri šteta pričinjena metalnoj industriji i rezultat postignut u njenoj obnovi. U obnovi metalne industrije mnogo je više učinjeno nego na obnovi tekstilne, koja je pretrpela sedam puta veću materijalnu štetu. Isti je slučaj sa drvnom i građevinskom industrijom, koje su u odnosu na ostale bile daleko manje oštećene, a čija je obnova brže napredovala. Svakako, na primeru drvne i građevinske industrije stvar je bila olakšavajuća jer su sredstva za njenu obnovu mogla da se nađu u samoj zemlji i zbog toga što tehnologija proizvodnje nije iziskivala kompleksnije mašine. Hemijska industrija je poseban primer: iako druga po procenjenoj šteti, uspela je da obnovi gotovo trećinu oštećenih kapaciteta. S druge strane, obnova tekstilne i prehrambene, jednih od najrazvijenijih industrijskih grana, sporo je napredovala tokom 1945. godine. Ovi podaci ne odražavaju pravu sliku stanja obnove na terenu, zbog toga što su obuhvaćena isključivo novčana sredstva utrošena za nabavku građevinskog materijala za obnovu zgrada, kupovinu novih $\mathrm{i}$ popravku oštećenih mašina, nabavku delova i instalacija i nadnice radnika koji su učestvovali u obnovi preduzeća. Iz toga proizilazi da su izuzeti besplatan rad, građevinski materijal i delovi koji su se mogli naći u samim fabrikama i postrojenjima. To navodi na zaključak da su postignuća na obnovi morala biti veća, ali koliko, to se pouzdano ne može utvrditi. Međutim, troškove obnove po narodnim republikama u 1945. godini možemo utvrditi. Prema raspoloživim podacima, u Hrvatskoj je utrošeno najviše sredstava (172 miliona dinara), posle nje u Srbiji (132 miliona), Sloveniji (86 miliona), Bosni i Hercegovini (49 miliona), Crnoj Gori (7 miliona) i Makedoniji (6 miliona). ${ }^{13}$ Josip Broz Tito je, sumirajući početkom 1946. godine dotadašnje rezultate na polju obnove, istakao da su ,naši narodi činili ogromne napore i postigli velike uspehe u obnovi razorene zemlje“, ${ }^{14}$ ali je podvukao da je tempo obnove sporiji od očekivanog za šta je po njegovom mišljenju krivac bila nedovoljno dobra privredna politika. ${ }^{15}$

\section{„Jednogodišnji plan obnove“6 - poslednja faza 1946-1947.}

Naredna, 1946. godina donela je nove principe u politici obnove zemlje. Ministar industrije i predsednik Komisije za privrednu obnovu zemlje Andrija Hebrang kritički je okarakterisao metod obnove primenjivan do tada rečima ,nedovoljno planski i organizaciono izgrađen." Sređivanjem situacije posle izbora za Ustavotvornu skupštinu, na kojima je lista predvođena od strane KPJ ostvarila apsolutnu pobedu, dalji pravac kretanja države na svim poljima više se nije dovodio u pitanje. Proces izgradnje državnog aparata usvajanjem Ustava krajem janua-

\footnotetext{
${ }^{13}$ AJ, SPK, 41-9-10, Prikaz predratne vrednosti, ratne štete i obnove industrije FNRJ u 1945. godini.

14 Борис Кидрич, O изградњи сочијалистичке економике ФНРЈ, Реферат одржан на V конгресу КПЈ (Београд: Централни комитет Комунистичке партије Југославије, 1948), 16.

15 Zapisnici sa sednica Politbiroa Centralnog komiteta KPJ (11. jun 1945-7. jul 1948), priredio Branko Petranović (Beograd: Službeni list SRJ, 1995), 140.
} 
ra 1946. samo je potvrdio realno stanje na terenu, a pred jugoslovenskim komunistima koji su suvereno vladali situacijom, otvorile su se šire perspektive odlučivanja o razvoju privrede. Već krajem 1945. godine stvoren je opšti konsenzus o donošenju sveobuhvatnog plana obnove. Na to je, osim učvršćivanja vlasti, uticalo nekoliko povezanih okolnosti. Među najvažnijim su: činjenica da je država upravljala velikim delom privrede, postojanje jakih masovnih organizacija u kojima je bila obuhvaćena gotovo sva radnička klasa, značajni uspesi u obnovi i znatna finansijska sredstva stvorena konfiskacijom imovine neprijatelja i njegovih saradnika. Veliku važnost imao je jednogodišnji plan proizvodnje čija je izrada bila u toku, a odlučeno je da plan obnove bude inkorporiran u njega, tako da predstavljaju jedan univerzalan plan. Završetak izrade oba plana priveden je kraju decembra 1945. godine, a planom obnove zacrtan je dovršetak obnove onih privrednih objekata koji će olakšati i ubrzati privredni razvoj cele zemlje. Nastavak obnove, drugim rečima, više nije trebalo da karakteriše neselektivan pristup kao tokom 1945. godine kada se stupilo u obnovu svega porušenog, već je trebalo obnavljati isključivo one privredne objekte kojima je u budućnosti namenjen ključni značaj za industrijalizaciju zemlje. Iza te premise krila se želja da se u nastavku obnove privreda kompletno reorganizuje $\mathrm{i}$ da se konačno raskrsti sa predratnom liberalnom ekonomskom doktrinom, kao i podelom rada koja je prema shvatanju jugoslovenskih komunista dovela do položaja u kome je Jugoslavija na svetskom nivou predstavljala ,pasivnog posmatrača“ osuđenog na trajnu zaostalost. ${ }^{16}$

Plan raspodele kredita bio je sastavni deo plana obnove. Ukupna suma novčanih kredita namenjenih za obnovu iznosila je 5,670 milijardi dinara, dok je visina materijalnih kreditnih sredstava ili kredita u robi (mašine, instalacije, alati, vozila) bila okvirno utvrđena na 4,690 milijardi, a njihova visina zavisila je prvenstveno od priliva pomoći od Administracije za pomoć i obnovu Ujedinjenih nacija (United Nations Relief and Rehabilitation Administration - UNRA) i reparacija. Sa preko 10 milijardi dinara namenjenih obnovi prioritet je dat industriji, rudarstvu, saobraćaju i elektrifikaciji na koje je otpalo 57\% sredstava. Industrija je dobila 832 miliona dinara, a najveća suma bila je namenjena drvnoj industriji. Radi racionalne eksploatacije šuma, koje su bile izvor jednog od najvažnijih izvoznih artikala, predviđena je suma od 233 miliona dinara. Ovako veliki iznos diktirale su potrebe racionalnije eksploatacije, jer je do tada uglavnom sečena šuma blizu komunikacija i to krajnje neracionalno, tako da je postala neophodna izgradnja komunikacionih objekata do šumovitih predela koji ranije nisu bili eksploatisani. Građevinska industrija je dobila 70 miliona dinara plus kratkoročna kreditna sredstva koje je trebalo da obezbedi Industrijska banka FNRJ, ${ }^{17}$ a sredstva su uglav-

${ }^{16}$ AJ, Kancelarija Maršala Jugoslavije (KMJ), 836/III-1/3, Predlog predsednika Savezne planske komisije A. Hebranga o izradi programa i plana obnove i izgradnje privrede i raspodela kredita prema privrednim granama (21. mart 1946), 1-3.

17 Industrijalizacija zemlje je iziskivala velika materijalna sredstva, a stvaranje Industrijske banke DFJ/FNRJ trebalo je da u najvećoj mogućoj meri obezbedi i racionalno raspodeljuje ta sredstva. Industrijska banka DFJ/FNRJ osnovana je dva meseca po oslobođenju zemlje, što jasno svedoči o prioritetima privredne izgradnje. Prvi akcionari upisali su akcije početkom jula 1945, čime je zapravo osnovana Državna industrijska banka a. d. sa centrom u Beogradu, a prvi akcionari bile su velike jugo- 
nom bila namenjena obnovi i investicijama za osposobljavanje proizvodnje $u$ ciglanama, crepanama, cementarama i krečanama. Sredstva namenjena hemijskoj industriji teritorijalno su podeljena tako da je na Srbiju otpadalo 32 miliona dinara kredita, Bosnu i Hercegovinu 23 miliona, Hrvatsku 20 miliona i Sloveniju 10 miliona dinara. Od te svote za ,veliko-hemijsku“ industriju predviđeno je 40 miliona dinara, a nju su trebalo da podele fabrika „Solway“ iz Lukavca za obnovu postrojenja za proizvodnju sode bikarbone, amonijačne i kaustične kiseline i fabrika „Zorka“ iz Šapca za investicije u svrhu proširenja pogona sumporne kiseline i za dovršenje novog najmodernijeg pogona za proizvodnju super fosfata. ${ }^{18}$

Metalnoj industriji je određen novčani kredit od 108 miliona dinara, a $47 \%$ od ove sume predviđeno je za teško postradalu fabriku vagona i mostova iz Slavonskog Broda. Imajući u vidu značaj metalne industrije za obnovu zemlje i posebno ove fabrike koja je bila najveća metaloprerađivačka fabrika u zemlji sposobna da proizvodi najveći deo uređaja i železničkih vozila za domaće potrebe, ne iznenađuje odluka da se gotovo polovina sredstava plasira u obnovu i izgradnju njenih fabričkih pogona, koji su uz smanjene kapacitete 1946. proizvodili tri lokomotive mesečno, a plan za 1947. predviđao je proizvodnju 50 lokomotiva i 1.000 vagona. Fabrike električnih uređaja nisu u ratu ozbiljnije postradale, ali zbog predstojeće elektrifikacije zemlje one nisu raspolagale dovoljnim kapacitetima koji bi mogli da podmire sve potrebe, pa je situacija nalagala proširenje postrojenja. Vodeći računa o savremenim principima proizvodnje, predviđena je maksimalna koncentracija tako da je čitav iznos za obnovu i izgradnju elektroindustrije podeljen na dva preduzeća. Bili su to fabrika „Rade Končar“ koja je trebalo da snabdeva zemlju motorima, transformatorima i ostalim uređajima jake struje, dok je predviđeno da fabrika u Kranju osigura masovnu proizvodnju uređaja slabe struje, kao što su radio-aparati, tonfilmski aparati, ručni elektroaparati, signalni uređaji i niz ostalih proizvoda. Predviđeni krediti za tekstilnu i prehrambenu industriju bili su najmanji uglavnom zbog toga što je kreditiranje trebalo da se vrši putem izdavanja kratkoročnih kredita najviše od strane Industrijske banke FNRJ, jer iako su spadale u najviše oštećene, cene mašina, instalacija i alata lake industrije bile su mnogostruko niže od onih za srednju i tešku. ${ }^{19}$

Kreditna sredstva bila su samo deo impulsa predviđenog da pokrene brži tempo obnove industrije, a drugi ništa manje značajan bio je dobrovoljni (neplaćeni) rad stanovništva, koji je u velikoj meri dao povoljne rezultate $\mathrm{i}$ to-

slovenske fabrike i država. Ministarstvo finansija DFJ/FNRJ upisalo je u prvoj tranši akcije u vrednosti od 200 miliona dinara, a najznačajnije fabrike koje su upisale akcije bile su „Beočinska fabrika a. d.“, „Šumsko Velebitno d. d.“ iz Belišće, „Našička tvornica tanina i paropila d. d.“ iz Zagreba, „Mitrovička tvornica šperploča d. d“ iz Sremske Mitrovice, „Raljska fabrika cementa a. d.“ iz Ralje (Beograd), Francusko-srpska industrija cementa i uglja iz Beograda, „Teokarević“ iz Paraćina, „Vistad“ iz Valjeva, „Zmaj“ iz Zemuna, „Utva“ iz Pančeva, „Jasenica“ iz Smederevske Palanke, „Tvornica vagona i mostova d. d.“ iz Slavonskog Broda, „Teleoptik“ iz Zemuna, ,Zorka“ iz Šapca, „Munk“ iz Zemuna i Fabrika stakla iz Pančeva. AJ, MIFNRJ, 17-2-2, Ovlašćenje Ministarstva industrije DFJ upraviteljima preduzeća o upisu akcija kod „Državne industrijske banke a. d.“ iz Beograda (4. jul 1945).

18 AJ, KMJ, 836/III-1/3, 4-6.

${ }^{19}$ Isto. 
kom 1945. godine. U dobrovoljnom radu prednjačila je omladina, u koju je Partija polagala najveće nade, a omladinske organizacije predvođene SKOJ, koristeći se svim raspoloživim agitaciono-propagandnim sredstvima, dobile su zadatak da podstaknu mladalački polet i udarništvo. ${ }^{20}$

Tako je 1. januar 1946. postao prvi dan sprovođenja planske obnove, ali sa bitnom novinom, a to je bila izgradnja. Sada se strogo vodilo računa da se sa što manje uloženih sredstava postigne što veći efekat i da se gde je to bilo moguće osigura maksimalna ušteda kako bi se ušteđena sredstva plasirala u proširenje kapaciteta najvažnijih preduzeća. Analiza hemijske i prehrambene industrije, koje su se prema stepenu oštećenja u ratu, a shodno svojim predratnim kapacitetima našle među prve tri industrijske grane, daje predstavu o tempu obnove. ${ }^{21}$

Obnova hemijske industrije gotovo da je privedena kraju do decembra 1946. godine, a za prvu polovinu 1947. ostavljen je manji broj preduzeća sa sitnijim problemima. Jedna od dve najveće fabrike hemijske industrije, fabrika „Solway“ iz Lukavca, u potpunosti je obnovljena za nepunih godinu dana i dodatno proširena. Već tokom obnove kako je koji pogon dovršavan, započinjala je proizvodnja koja je posle puštanja svih pogona u rad davala sirovine za mnoge druge industrijske grane (tekstilnu, industriju sapuna i industriju stakla). Na ušću reke Cetine u Jadransko more, u mestu Dugi Rat, proces rekonstrukcije završila je fabrika „Dalmatia d.d.“. Ova fabrika karbida i cijanamida je već svojim položajem, između planine Perun u zaleđu i same obale mora, bila prirodno okrenuta ka izvozu, kao i u predratno vreme. Obnovu je privela kraju i fabrika za destilaciju drva u Tesliću, a fabrika hartije iz Beograda je pružila najbolji primer uspešne koordinacije inženjera i radnika, koji su za kratko vreme uz maksimalno poštovanje plana dovršili obnovu i punim kapacitetima startovali sa proizvodnjom. ${ }^{22}$ Fabrika „Merima“" iz Kruševca je pozitivan pokazatelj kako efikasne obnove, tako i uspešne izgradnje u kojoj su postrojenja modernizovana i opremljena najnovijim mašinama, a proizvodni kapaciteti pojedinih postrojenja time povećani čak pet puta. ${ }^{23}$

Najveća fabrika hemijske industrije ,Zorka“ iz Šapca bila je tokom rata pod striktnom kontrolom Nemaca, a ceo posao vodili su visoko kvalifikovani majstori iz Nemačke, koji su imali isključivo pravo da rukuju mašinama dopremljenim iz Nemačke za potrebe savremenije produkcije. Predratni radnici „Zorke“ su kao pomoćno osoblje bili lišeni obuke i uopšte pristupa mašinama, ali to ih nije sprečilo da uče pažljivo gledajući nemačke majstore. Završetak rata zatekao je fabriku samo delimično oštećenu, a to oštećenje okupator je pričinio uništenjem piritne peći prilikom povlačenja, dok su ostale mašine ostale sačuvane. Pomoću tehničkih stručnjaka i angažovanjem radnika peć je sanirana već početkom januara 1946. i time je fabrika bila u potpunosti obnovljena. Značaj fabrike „Zorka“ za

\footnotetext{
${ }^{20}$ Isto; AJ, MI FNRJ, 17-8-8, Referat B. Kuglera komesara Komisije za privrednu obnovu zemlje o planu obnove za 1946. godinu (29. januar 1946).

${ }^{21}$ Isto, $1-3$.

22 AJ, SPK, 41-8-9, Obnova hemijske industrije u 1946. godini.

23 AJ, MI FNRJ, 17-145-146, Izveštaj o radovima na obnovi fabrike „Merima“ iz Kruševca za 1946. godinu (1947).
} 
celu privredu, a posebno poljoprivredu, bio je ogroman. Činjenica da je tokom rata modernizovana dopremanjem savremenih mašina iz Nemačke i proširenjem pogona od strane okupatora, kao i uvođenjem nove organizacije rada po nemačkom modelu, doprinela je da „Zorka“ startuje sa daleko viših pozicija nego što su bile one pre rata. ${ }^{24}$ Ostale hemijske fabrike, procentualno nešto manje oštećene, do kraja godine su sanirane i stavljene u pogon. Troškovi obnove hemijske industrije iznosili su više od 80 miliona dinara, a ušteda na bazi iskorišćenja starog materijala i dobrovoljnog rada prelazila je sumu od 20 miliona. Ovom sumom nisu obuhvaćeni svi radovi, jer nije uračunat doprinos Jugoslovenske armije, koja je svojim radom osposobila mnoga preduzeća. ${ }^{25}$

Prehrambenoj industriji u Kraljevini Jugoslaviji nije se poklanjalo dovoljno pažnje, iako je ona prema privrednoj strukturi zemlje i sirovinskim bazama kojima se raspolagalo mogla da bude na daleko većem stepenu industrijalizacije i tehnološkog razvoja. Sirovine su se uglavnom izvozile da bi se kasnije vraćale kao gotovi proizvodi. Neprijatelj je u toku rata dodatno unazadio prehrambenu industriju uništivši ili oštetivši nešto više od $2 / 3$ preduzeća, a tokom 1945. godine obnovi ove grane nije se pristupilo u većoj meri. Jedan od razloga ležao je u tome što su privredni planeri hteli bolje da rasporede postojeće pogone i da ih ukrupne, jer su to bila većinom mala preduzeća pa ih je trebalo fuzionisati i prilagoditi savremenim obrascima proizvodnje radi postizanja veće efikasnosti. Tako je od 1.459 predratnih preduzeća likvidirano njih 306, a rad je nastavilo svega 1.153 preduzeća. ${ }^{26}$

Obnova u 1946. bila je bolje osmišljena i tempo je značajno ubrzan. $\mathrm{Na}$ prvom mestu postavilo se pitanje brzog osposobljavanja mlinova, kojima je procentualno naneta najveća šteta. U kratkom periodu tokom 1946. obnovljeno je preko $85 \%$ predratnih kapaciteta, a industrija testenina koja je pretrpela $25 \%$ štete brzo je osposobljena i unapređena, pa je već 1946. povećala kapacitete za $15 \%$ u odnosu na pre rata. U industriji špiritusa obnovljeno je $91 \%$ kapaciteta, a svih 27 pivara koje su radile u Kraljevini Jugoslaviji obnovljeno je do kraja 1946. godine. Rekvizicijom stoke od strane okupatora stočni fond je pretrpeo ogromnu štetu, a posledica toga bio je nedostatak masnoća u svakodnevnoj ishrani stanovništva. Kako bi brzo prebrodili taj nedostatak, privredni rukovodioci uložili su velike napore da što pre obnove i prošire kapacitete uljarske industrije. To je rezultiralo ne samo apsolutnim uspehom obnove, već i povećanjem kapaciteta za 25\%. Dobar primer je državna fabrika ulja „Domaća“ iz Novog Vrbasa, koja je po kapacitetu prerade sirovina suncokretovog semena bila druga u zemlji. Angažovanjem stručnjaka radnici fabrike uspeli su da skrate proces proizvodnje za $50 \%$, a proizvodnja je premašila predratnu tehničku normu za isti procenat. Izvršene su inovacije na kotlovima pa su, pored nafte i uglja, mogli da se koristi otpaci od suncokreta (ljuske) za loženje. Šećerna industrija obnovila je predratne kapacitete podjednako brzo, ali ono što je predstavljalo

\footnotetext{
${ }^{24}$ Политика, 12. 1. 1946.

${ }^{25}$ AJ, SPK, 41-8-9, Obnova hemijske industrije u 1946. godini.

${ }^{26}$ AJ, SPK, 41-8-9, Obnova prehrambene industrije u 1946. godini.
} 
problem bila je šećerna repa čiji je rod podbacio usled velike suše leta 1946, pa je tokom godine radila sa $1 / 3$ kapaciteta. $^{27}$

Obnovom jednog po jednog pogona, jedne po jedne fabrike, proizvodnja je rasla gotovo iz dana u dan. Nepisana dužnost svakog preduzeća - da deo dobiti uplati u Fond za obnovu zemlje - bila je samo jedan segment pomoću koga je država obezbeđivala stalan priliv sredstava za obnovu i izgradnju zemlje. Drugi faktor koji je značajno doprinosio obnovi bio je usko vezan za donje spratove organizacije, lokalnog i okružnog značaja, koji su ,sklapajući slagalicu“ na mikro prostoru olakšavali ,kristalisanje slike“" na makro nivou. Tako je državna pilana „Šipad“ iz Zavidovića pomogla da susedna pilana „Našička“ stane ,na svoje noge“" marta 1946, da bi potom združenim snagama počeli da snabdevaju građom obnovu železničkih koloseka i mostova centralne i istočne Bosne. Vredan pomena je napor koji je „Šipad“ uložio tokom jeseni i zime 1945. godine, kada je železničkim radnicima obezbedio materijal kojim je obnovljeno 50 mostova i postavljeno 80.000 novih pragova na šumskoj pruzi Zavidovići - Han-Pijesak dugoj 113 kilometara. U mašinskoj radionici fabrike „Šipad“ vršile su se i opravke lokomotiva i vagona uskog koloseka bosanskohercegovačke drvne industrije. Inače, ove dve pilane su tokom 1946. godine snabdevale pilonima obnovu Pančevačkog mosta, a time je ova četvorostruka uloga najbolje ilustrovala značaj jednog preduzeća u privrednoj obnovi na liniji lokal - okrug -republika - savezna država. ${ }^{28}$

Osnivanju i jačanju državnog sektora u građevinarstvu pridavao se od oslobođenja zemlje ogroman značaj. Razvoj državnih preduzeća u narodnim republikama je već tokom 1945. zabeležio značajne rezultate, a Slovenija je u tom pogledu najviše odmakla. Novoosnovana državna građevinska preduzeća u Sloveniji prednjačila su u domenu organizacije i kapaciteta naspram preduzeća iste vrste u ostalim republikama. Tako je u Sloveniji državno preduzeće „GRADIS“، obuhvatilo skoro sav građevinski inventar koji je zatečen posle rata i organizaciono razgranalo mrežu preduzeća po dubini, koja su potom postala deo jedne čvrsto međusobno povezane i visoko centralizovane strukture. U Hrvatskoj je primenjen drugi princip, jer su osnovani Zemaljsko građevinsko preduzeće Hrvatske u Zagrebu i 16 okružnih građevinskih preduzeća, koja su bila organizaciono samostalna. Sva ta preduzeća su sa manje ili više uspeha učestvovala u obnovi tokom 1945. U Bosni i Hercegovini obrazovano je Zemaljsko preduzeće u Sarajevu i nekoliko okružnih preduzeća, od kojih je banjalučko pokazalo najbolje rezultate. Zemaljsko preduzeće u Skoplju bilo je jedino preduzeće tog tipa koje je osnovano u Makedoniji tokom 1945. Srbija je na tom polju postigla relativno najslabiji rezultat, jer se republičke vlasti nisu dovoljno potrudile da spreče raspodelu građevinskog inventara i mašina ostalim ministarstvima, pa je formirano svega jedno zemaljsko, jedno gradsko i jedno okružno preduzeće, dok se tokom 1945. ubrzano radilo na osnivanju još šest okružnih preduzeća. Rezultat svega toga bio je koncem godine takav da se državni građevinski sektor Srbije nije mogao uporediti sa snagom preduzeća u Sloveniji i Hrvatskoj, ni po količini građevinskog inventara,

\footnotetext{
${ }^{27}$ Isto.

${ }^{28}$ Политика, 5. 4. 1946.
} 
ni po sposobnosti za rad. Situacija se, međutim, tokom 1946. drastično popravila zahvaljujući prilivu pomoći od UNRE. ${ }^{29}$

Rezultati obnove industrije do kraja 1946. bili su veoma uspešni. Planeri obnove mogli su odahnuti, jer je plan gotovo do kraja izvršen. Brza obnova zemlje, uslovljena prelaskom na potpuno planiranje po sistemu sovjetskih ,pjatiljetki" koje je trebalo da počne krajem aprila 1947, davala je prostora da se za tih nekoliko meseci 1947. obnova u potpunosti privede kraju. Zbog oskudice raspoloživih jedinstvenih statističkih podataka obnove industrije u 1946. godini, jedini preostali metod ispitivanja rezultata obnove može se izvršiti putem uzorka. Pošto su predstavljeni rezultati obnove i delimično izgradnje hemijske i prehrambene industrije, preostaje da se analizira stepen obnove ostalih industrija na uzorku od preko 100 industrijskih preduzeća koja su dostavila podatke u 1946. godini. Rezultati koji su proizašli iz tog ispitivanja pokazuju da je u 1946. obnovljeno 96\% predratnih kapaciteta koji su u ratu doživeli destrukciju, što jasno ukazuje da je obnova bila gotovo privedena kraju. ${ }^{30}$

Pregled sredstva utrošenih na obnovu industrije upotpunju celokupnu sliku. Tako je za obnovu i izgradnju utrošeno 2,029 milijardi dinara. Ako se ta sredstva stave u kontekst štete koju je trebalo ukloniti tokom godine, a koja je iznosila 2,461 milijardu dinara, proizilazi da je pomoću ovih sredstava moglo biti sanirano $82 \%$ štete. Međutim, dobrovoljni ili neplaćeni rad i besplatni izvori materijala, koji nisu ukalkulisani u ovu sumu, bili su jedan od najvažnijih činilaca obnove i izgradnje zemlje, čije je korišćenje značajno doprinosilo saniranju štete. Time, procenat dobijen na osnovu uzorka izgleda više nego približan i možemo slobodno reći da ocrtava pravu sliku stanja na terenu. ${ }^{31}$

Brzina i efikasnost obnove teške industrije, koja je shodno tehnološkim merilima najsloženija, pruža dobar uvid u rekonstrukciju strateški najvažnijeg sektora privrede. Fabrika lokomotiva, mostova i strojeva „Đura Đakovićc iz Slavonskog Broda, koja je bila oštećena preko 50\%, obnovu je završila do 31 . decembra 1946. godine. Elektrometalurški kombinat iz Šibenika, oštećen preko 85\%, rekonstrukciju je priveo kraju takođe do 31. decembra 1946. „Vojvođanska livnica“ iz Novog Sada je zbog teških oštećenja zadatke obnove izvršila do sredine novembra 1947, dok je fabrika motora iz Rakovice koja je bila oštećena 30\% obnovu dovrši-

\footnotetext{
${ }^{29}$ Tehnika, III, mart 1946, 90.
}

${ }^{30}$ AJ, MI FNRJ, 17-145-146, Rekapitulacija izveštaja o radovima na industrijskoj obnovi zemlje u 1946. godini; AJ, MI FNRJ, 17-147-148, Mesečni izveštaji o obnovi tvornica i preduzeća u 1946. godini; AJ, SPK, 41-24-46, 47; AJ, SPK, 41-25-50, Izveštaji o privrednoj obnovi zemlje 1946. godine; AJ, SPK, 41-27-53, Izveštaji o privrednoj obnovi zemlje 1946. godine.

${ }^{31}$ AJ, KMJ, 836/III-1/9, Pregled utrošenih suma za obnovu i izgradnju po privrednim granama u toku 1946. godine, 1-2. Kao ilustracija o kakvim je naporima i odricanjima reč svedoče podaci o radnim kolektivima 12 preduzeća teške industrije, čiji su radnici dali ogroman doprinos obnovi. Radnici ovih fabrika dali su preko 800.000 dobrovoljnih časova rada, odnosno preko 100.000 besplatnih nadnica. Među preduzećima su se naročito istakli: kolektiv fabrike vagona - Kraljevo (215.000 časova); kolektiv industrije lokomotiva, mostova i strojeva „Đura Đaković“ - Slavonski Brod (110.000 časova); kolektiv industrije motora iz Rakovice (92.000); kolektiv elektrometalurškog kombinata iz Šibenika (80.000 časova). AJ, Ministarstvo teške industrije Vlade FNRJ (MTI FNRJ), 16-3-3, Referati o teškoj industriji dostavljeni Vlajku Begoviću, Obnova naše teške industrije, 2. 
la još novembra 1945. Treba, međutim, imati u vidu da je u većini preduzeća produkcija vršena uporedo sa obnovom. Pojedina preduzeća su, uz to, organizaciono rekonstruisana i prevođena na novu vrstu produkcije tokom same obnove. ${ }^{32}$

Ekonomista Mijo Mirković je smatrao da se jedan od glavnih razloga efikasne obnove nalazio u primarno brzoj obnovi glavnih saobraćajnica, na prvom mestu železnice, navodeći da je pruga Beograd-Zagreb obnovljena za svega 70 dana. Uz železnicu, ističe M. Mirković, presudnu ulogu odigrali su kamioni i prikolice koje je Jugoslavija dobila prvo od Savezničke komande za Mediteran (1.182 kamiona), a potom i od UNRE koja je isporučila 7.474 kamiona, 2.679 prikolica i 2.000 traktora $^{33}$ do kraja 1945 . godine. ${ }^{34}$ Vrednost pomoći se najbolje vidi ako se razmatranje spusti na mikro nivo, na nivo srezova (danas opštine) i gradova u rangu sreza, kojih je krajem 1946. bilo 407, odnosno 75. To pokazuje da je na jedan srez ili grad u tom rangu dolazilo u proseku 18 kamiona, 5-6 prikolica i 4 traktora. $^{35}$ Samo osam godina ranije, 1938. godine, u Jugoslaviji je u proseku na jedan srez ili grad dolazilo 8 kamiona i nijedna ili jedna prikolica. Stoga je na početku 1946. situacija u pogledu kamiona i prikolica bila daleko bolja od one pre rata, a ako uporedimo predratni broj kamiona (3.859) sa brojem koji je dobijen zahvaljujući pomoći spolja (8.656), vidimo da ih je bilo više za 124\%, dok je broj kamionskih prikolica u istom poređenju čak za $1.600 \%$ bio veći nego 1938 . godine. ${ }^{36}$

Gotovo polovina ovih kamiona je korišćena tokom rata, pa je za njihov remont brigu preuzelo novoosnovano Državno automobilsko saobraćajno preduzeće (DASP). ${ }^{37}$ Ovde nisu uračunati kamioni koji su iz rata izašli neoštećeni ili blago oštećeni i oni koji su dobijeni od SSSR-a ili pak zarobljeni u borbi protiv okupatora, a broj takvih nije bio mali. Stoga su procenti pomoću kojih se porede ova dva bilansa samo jedan segment šireg okvira transportnih mogućnosti na početku planske obnove. Drugim rečima, prosek kamiona po jednom srezu bio je mnogo veći od $18 .^{38}$ Krajem 1946. raspolagalo se sa 12.030 kamiona, što je povećanje od $212 \%$ u odnosu na predratno stanje. ${ }^{39}$ Podjednako važnu ulogu u planskoj obnovi, po oceni M. Mirkovića, imale su novouspostavljene organizacione forme državnog delovanja, kao i disciplinovano vođene finansije koje su omogućile da se na prvom mestu inflacija ,saseče u korenu“, a potom da se sredstva ne rasipaju bespotrebno, već da se efikasno utroše isključivo na planom utvrđene objekte. ${ }^{40}$

\footnotetext{
32 AJ, MTI FNRJ, 16-3-3, Referati o teškoj industriji dostavljeni Vlajku Begoviću, Obnova naše teške industrije, $2-3$.

33 Jugoslavija je u svojim nabavkama preko UNRE tražila isporuku ukupno 5.000 traktora, a do aprila 1946. isporučeno je 2.700 traktora. Borba, 13. 4. 1946.

${ }^{34}$ Mijo Mirković, Izgradnja socijalističke ekonomije u Jugoslaviji (Zagreb: Otokar Keršovani, 1979), IV, 68-69.

${ }^{35}$ Statistički godišnjak FNRJ za 1954. godinu (Beograd: Savezni zavod za statistiku, 1954), 31.

36 Статистички годишњак Краљевине Југославије за 1939. годину (Београд: Општа државна статистика, 1939), 210.

${ }^{37}$ Branko Petranović, „Pomoć UNR-e Jugoslaviji“, Istorija XX veka, br. 2, (1961), 192-193.

${ }^{38}$ Статистички годишњак Краљевине Југославије за 1939. годину, 210.

${ }^{39}$ AJ, KMJ, 836/III-1-9, Pregled utrošenih suma za obnovu i izgradnju po privrednim granama u toku 1946. godine (1947. godina), 9.

${ }^{40}$ M. Mirković, n. d., 61-68.
} 


\section{REFERENCE}

- Dimić, Ljubodrag. Agitprop kultura: agitpropovska faza kulturne politike u Srbiji: 1945-1952. Beograd: Rad, 1988.

- Gaćeša, Nikola L. Istorija fabrike cementa u Beočinu. Novi Sad: Matica srpska, 2008.

- Kidrič, Boris. O izgradnji socijalističke ekonomike FNRJ, Referat održan na V kongresu KPJ. Beograd: Centralni komitet Komunističke partije Jugoslavije, 1948.

- Mirković, Mijo. Izgradnja socijalističke ekonomije u Jugoslaviji. Zagreb: Otokar Keršovani, 1979, IV.

- Petranović, Branko. „Pomoć UNR-e Jugoslaviji“. Istorija XX veka, br. 2, (1961), 163-224.

- Petranović, Branko. Srbija u Drugom svetskom ratu: 1941-1945. Beograd: Vojnoizdavački i novinski centar, 1992.

ALEKSANDAR RAKONJAC, MA, Research Trainee

Institute for Recent History of Serbia

Belgrade, Republic of Serbia

aleksandar.rakonjac90@gmail.com

RECONSTRUCTION OF YUGOSLAV INDUSTRY 1944-1947. IDEAS, PLANS, PRACTICE

\section{Summary}

Article explores the dynamic time of economic reconstruction of Yugoslavia after World War II. The main part is devoted to the reconstruction of industry, which in economic conception of Yugoslav Communists occupied a key position. In rebuilding of industrial capacities, the state has approached in two phases, according to the methods of state intervention characterized as "unplanned" and "planned" stage. During 1945, political circumstances and little experience in managing the economy, conditioned a voluntaristic approach to the reconstruction of destroyed industrial plants. The beginning of 1946 was a turning point, because the state adopted a one-year plan of reconstruction of the country, which precisely defined what and how should be restored, and the organization is therefore raised to a much higher level than in 1945. Overall conditions were permanently repaired during 1946, which resulted in great achievements in the field of reconstruction, and by April 1947 the reconstruction of the Yugoslav industry was finalized.

KEYWORDS: Yugoslavia, industry, reconstruction, planning, Communist Party of Yugoslavia 